DOI: $10.15372 / H S S 20150309$

УДК 94(47)»1921/1922»

\title{
А.Л. ПОСАДСКОВ
}

\section{ПИСАТЕЛЬ ВС. Н. ИВАНОВ ВО ГЛАВЕ ИЗДАТЕЛЬСКОГО ДЕЛА ВРЕМЕННОГО ПРИАМУРСКОГО ПРАВИТЕЛЬСТВА (1921-1922 гГ.)}

\author{
Александр Леонидович Посадсков, \\ д-р ист. наук, проф., главный научный сотрудник, \\ Государственная публичная научно-техническая библиотека СО РАН, \\ РФ, 630200, Новосибирск, ул. Восход, 15 \\ e-mail: knigoved@spsl.nsc.ru
}

\begin{abstract}
Статья посвящена истории издательских учреждений Временного Приамурского правительства братьев С.Д. и Н.Д. Меркуловых, существовавшего в Приморье в мае 1921 - июне 1922 г. Освещается роль писателя и журналиста Вс. Н. Иванова в организации и деятельности этих структур печатной пропаганды Белого движения на востоке России. До октября 1921 г. Вс. Н. Иванов являлся уполномоченным меркуловского правительства по информации, осуществлял функции прямого управления издательским делом «белого» Приморья. Позднее Вс. Н. Иванов стал одним из организаторов формально независимой, но фактически финансируемой правительством организации «Дальневосточный союз русских журналистов» с крупным издательским отделом, который заменил прежнее официальное Пресс-бюро. Анализируется работа Вс. Н. Иванова как редактора «Вечерней газеты» и других изданий, выходивших во Владивостоке в этот период, эволюция его общественной позиции.
\end{abstract}

Ключевые слова: периодическая печать, Приморье, Временное Приамурское правительство, Вс. Н. Иванов, Белое движение, журналистика, издательское дело.

\section{A.L. POSADSKOV}

\section{WRITER VS. N. IVANOV AS HEAD OF PUBLISHING OF THE PROVISIONAL PRIAMURYE GOVERNMENT (1921-1922)}

\author{
Alexander L. Posadskov, \\ Doctor of Historical Sciences, Chief Researcher, \\ State Public Scientific-Technological Library SB RAS \\ 15, Voskhod Str., Novosibirsk, 630200, Russia \\ e-mail: knigoved@spsl.nsc.ru
}

The famous Soviet Far Eastern writer Vsevolod Nikanorovich Ivanov (1888-1971) began his literary career in 1918-1922 as the White Guard journalist and employee of the Russian Society of Typographic Arts in Omsk (1919), the author of journalistic and literary works published in emigrant press of China of the 1920s. There already exists a vast literature on his life and career. However, in particular, his activity in May 1921 - October 1922 in Primorye, which was then under the White Guard government control, is little known to the researchers studying the history of periodical press and literature. The article is intended to fill this information gap.

Vs. N. Ivanov was an active participant of revolution on May 26,1921, which brought Primorye under the «national and democratic» government headed by brothers S.D. and N.D. Merkulov. On the day of revolt Merkulovs appointed him as Commissioner for Information in the new government. Since that time the daily «Evening Newspaper» had been published as the government's informal loud-hailer under Vs. Ivanov's edition. In short time Vs. Ivanov created the Government Press Office, arranged a regular release and distribution of anti-Bolshevist literature. He also selected managerial personnel for anti-Communist propaganda (G.G. Nedler, Ya.L. Beloblotsky, P.P. Vasilyev, et al.)

In November, 1921 Vs. Ivanov and his assistants undertook reorganization of propaganda department by analogy with the reform carried out in the «white» Omsk in May 1919, when the governmental Press-Bureau was replaced by a joint-stock enterprise of the Russian Society of Typographic Arts. In Vladivostok the Press-Bureau was also closed, and the Far Eastern Union of Russian Journalists was created. It had a large publishing department and was formally independent (but secretly financed by the Government). The publishing house started a large-scale activity, publishing two specialized editions for peasants and having at its disposal the newspapers "Slovo" and "Russky kray" in Vladivostok.

The capture of Vladivostok by the National-Revolutionary Army of the Far Eastern Republic and «red» guerrillas put an end to this printed propaganda machine. Vs. I. Ivanov left the city on October 22, 1922, three days before the collapse of the «white» government.

Key words: periodicals, Primorye, Priamurye Provisional Government, Vs. N. Ivanov, the White movement, journalism, publishing.

(C) Посадсков А.Л., 2015 
Фигура классика дальневосточной советской литературы Всеволода Никаноровича Иванова (18881971) в последние годы привлекает все бо́льшее внимание исследователей. Необычная судьба влиятельного белогвардейского и эмигрантского журналиста, ставшего известным советским писателем, вместила опыт восьми десятилетий истории. Вышла в свет монография хабаровской исследовательницы С. И. Якимовой о жизненном пути Вс. Н. Иванова [1], под ее же редакцией выпускаются сборники статей об Иванове, в Тихоокеанском государственном университете проводятся конференции, посвященные творчеству писателя. Дальневосточная государственная научная библиотека издала биобиблиографический указатель, посвященный Вс. Н. Иванову [2], а Гродековский (краевой) музей в Хабаровске - его дневник и записные книжки за 1944-1965 гг. [3]. Увидела свет статья и подборка документов о начале деятельности Bc. Н. Иванова в Белом движении на востоке России [4]. Неподдельный интерес вызывают и откровенные, не отредактированные советскими цензорами воспоминания самого Всеволода Никаноровича, сокращенный вариант которых публиковался в 1990-е гг. в журнале «Дальний Восток», а затем был издан отдельной книгой [5] (полная пятитомная рукопись воспоминаний еще ждет своего издателя).

Но биография этого удивительного человека таит в себе много неизученного. Данная статья посвящена одной из ее малоизвестных страниц - периоду с мая 1921 г. по июнь 1922 г., когда Вс. Н. Иванов достиг высшей точки в своей карьере «белого» журналиста и издателя: стал руководителем всей официальной издательской деятельности в Приморье под эгидой Временного Приамурского правительства братьев С.Д. и Н.Д. Меркуловых.

Белогвардейский переворот, поставивший у власти во Владивостоке братьев Меркуловых и свергнувший «розовую» эсеро-большевистскую власть Временного правительства Дальнего Востока, произошел, как известно, 26 мая 1921 г. Но его подготовка началась намного раньше, и Вс. Н. Иванов имел к ней прямое отношение. По его словам, он прибыл во Владивосток «в снежном сыром марте 1921г.» [5, c. 369] для подготовки организационного центра заговорщиков - «Съезда несоциалистического населения Дальнего Востока».

Идея созыва такого съезда вышла из недр редакции газеты «Слово», издававшейся Н.Д. Меркуловым. Вс. Н. Иванов искренне восхищался в то время Н.Д. Меркуловым, с которым он случайно познакомился в 1920 г. Фабрикант Николай Меркулов представлялся ему выразителем лучших национальных черт русского народа: прямоты, напористости, открытости, деловитости, социального оптимизма. Во Владивостоке Вс. Н. Иванов познакомился и близко сошелся с другим организатором переворота из окружения Меркуловых - с однофамильцем Василием Федоровичем Ивановым, юристом, публицистом и философом, будущим премьер-министром меркуловского кабинета. Вс. Н. Иванов был в курсе деятельности подпольной меркуловской организации - «Национально-революционного комитета», в который входил В.Ф. Иванов. Всеволод Никанорович являлся к тому же секретарем второго «несоциалистического съезда», который, собравшись в мае 1921 г. (первый съезд прошел в марте), избрал Совет съезда несоциалистических организаций во главе с С.Д. Меркуловым - pуководителем новой «национально-революционной» власти в Приморье. Тем самым съезд санкционировал переворот. Днем 26 мая 1921 г. вооруженные отряды «каппелевцев» подавили сопротивление защитников прежнего полукоммунистического режима, и Временное Приамурское правительство (ВПП) приступило к работе. В этот же день Вс. Н. Иванов получил от С.Д. Меркулова мандат уполномоченного ВПП по информации [5, с. 377].

В сущности, это была «комиссарская» должность. Никаких инструкций, «правил игры» к мандату не прилагалось. Вс. Н. Иванов должен был сам определить круг своих полномочий, цели и ближайшие задачи работы, структуру управления, штаты и стиль поведения. Единственной директивой Иванову стал правительственный указ об издании официальных «Известий Временного Приамурского правительства». Газета с таким названием начала выходить под редакцией Вс. Н. Иванова с 27 мая.

Сохранился документ, на основе которого в дальнейшем строилась почти вся издательская деятельность ВПП в области прессы и издательства: «Пояснительная записка к схеме деятельности уполномоченного по информации». Правка и дополнения к этой бумаге, написанные характерным почерком Bc. Н. Иванова, не оставляют сомнения в его авторстве. Документ, по-видимому, создавался в первые же дни после переворота. Подробно описав и высоко оценив поставленную «почти на идеальную высоту» большевистскую пропаганду в России, Иванов делает вывод о том, что учесть опыт «красной» издательской деятельности «является насущно необходимым». Сообщая, что «население территории, подведомственной Временному Приамурскому правительству, еще не получает пока никакой антикоммунистической литературы», Иванов подчеркивает важность усиленного финансирования печатных изданий правительства: «излишняя экономия в денежных средствах может в высшей степени вредно отразиться на деле антибольшевистской пропаганды». Как человек, имеющий большой опыт работы в колчаковском Русском бюро печати, Вс. Н. Иванов сообщает ВПП, что им сформирована во Владивостоке организация под названием «Пресс-бюро», для которой подыскивается подходящий служебный персонал. План Вс. Н. Иванова намечал также издание неофициальной (формально независимой) ежедневной газеты «Русский край», которая начала выходить во Владивостоке с 2 июня 1921 г. под редакцией поручика П.П. Васильева - из- 
вестного в «белой» Сибири общественного деятеля, друга Вс. Н. Иванова и его спутника во время бегства от большевиков зимой 1919/1920 гг.

Рассчитывая на широкую постановку печатной пропаганды ВПП, Вс. Н. Иванов намечает и ряд других мер. Он пишет: «Независимо от официальных изданий правительства, для распространения в населении антикоммунистических идей, мною при Пресс-бюро предположено основать литературный и художественный отделы, коими будут выпускаться различные листовки, брошюры... плакаты и пр.».

$\mathrm{B}$ «Пояснительной записке» Вс. Н. Иванова предусматривается и организация распространения печатной продукции ВПП: «Для более скорого и планомерного проведения в среду населения изданий Пресс-бюро мною разрабатывается сеть информации, служебный персонал которой будет вырастать по мере увеличения территории, подведомственной Временному Приамурскому правительству. Для обслуживания сети информации населения будет организована служба как разъездных агентов, так и агентов на местах».

К «Записке» Вс. Н. Иванов прилагал схемы «деятельности уполномоченного по информации» (т.е. очерчивал круг своих служебных полномочий), «организации Пресс-бюро» и «схему личного состава Пресс-бюро» ${ }^{1}$. Он просил ВПП утвердить эти схемы, что, очевидно, и было сделано, поскольку все дальнейшие события в издательском деле Приморья полностью соответствовали изложенному плану. В этом смысле Вс. Н. Иванов вполне может рассматриваться как творец меркуловской пропагандистской машины.

В день переворота Вс. Н. Иванов нашел человека, который возглавил Пресс-бюро. Им стал капитан-лейтенант флота, бывший служащий Морского министерства в Омске Герман Германович Недлер. Документ о приеме его на службу подписан Вс. Н. Ивановым 26 мая 1921 г. $^{2}$ Причем сам Иванов утверждает в воспоминаниях, что Г.Г. Недлер просто явился к нему в числе других посетителей и предложил свои услуги [5, с. 378-379]. Военных, особенно «каппелевцев», охотно брали на службу в аппарат Пресс-бюро: так, разъездным агентом работал полковник артиллерии С.Г. Закржевский, штабс-капитан А.М. Седлецкий был рассыльным, как и военный чиновник, губернский секретарь С.В. Майшев ${ }^{3}$. На должностях в Пресс-бюро оказались и бывшие гражданские чины, студенты, а среди корреспондентов во Владивостоке и на местах - бывшие журналисты белогвардейских газет (И.В. Свитланов, Ф.В. Лодейщиков, А.М. Катенёв и др. $)^{4}$. Но благосклонность Иванова и Недлера не распространялась на представителей

${ }^{1}$ Российский государственный исторический архив Дальнего Востока (РГИА ДВ). Ф. Р-718. Оп. 1. Д. 3. Л. 8-9.

2 Там же. Д. 7. Л. 70-71.

${ }^{3}$ Там же. Л. 29, 31-38, 68-69, 99-100.

${ }^{4}$ Там же. Л. 6, 54-55, 58-61, 63; Д. 5. Л. 5. журналистики, связанных с атаманом Г.М. Семеновым. Один из них, С.В. Гортинский (Г. Тинский), перебравшийся из Читы в Токио, жаловался члену руководства Несоциалистического съезда С.П. Рудневу на холодный прием у Вс. Н. Иванова. В июне 1921 г. Гортинский приехал во Владивосток, где, как он сообщал, «при разговоре с Вс.Н. Ивановым ничего конкретного я добиться не мог» и отказался по этой причине «помочь делу, не имея никаких полномочий» 5 .

30 мая 1921 г. меркуловское правительство утвердило временный штат Пресс-бюро из 6 чел., оговорив при этом, что бюро «находится в непосредственном ведении и распоряжении уполномоченного по информации». 18 августа 1921 г. Совет управляющих ведомствами ВПП утвердил уже расширенные штаты Прессбюро и «Вестника ВПП» в составе 22 служащих ${ }^{6}$. Упомянутый «Вестник», как и намечал Вс.Н. Иванов, начал выходить 25 июня 1921 г. вместо «Известий». Редакторство в нем совмещал с работой в Пресс-бюро Г.Г. Недлер. Пресс-бюро, как и кабинет уполномоченного по информации, находились прямо в резиденции правительства - в здании Морского штаба.

О том, с каким настроением взялся Вс. Н. Иванов за налаживание печатной пропаганды ВПП, говорят его публикации этих месяцев. Иванов не уставал подчеркивать, что ВПП - «первое национальное правительство за всю нашу революцию» ${ }^{7}$ и к тому же - единственное из всех «белых» правительств России - не военное, а гражданское. В ВПП не было ни одного генерала, даже военный и морской министр Н.Д. Меркулов никогда не носил погон.

Строки, вышедшие из-под пера Вс. Н. Иванова, показывают, что он прекрасно сознавал всю неустойчивость приморской политической конструкции перед лицом надвигающейся «красной» России. Тем сильнее было его желание содействовать сохранению приморского анклава, где, по его пониманию, воцарилась, наконец, «национальная демократия», а с нею - мирная сытая жизнь, стремление к правопорядку и развитию экономики. «Мы твердо уверены, - писал Bc. Н. Иванов, - что из всего того ада, который в настоящее время представляет из себя Россия, Приморье есть самый счастливый уголок» ${ }^{8}$.

Помимо собственной печатной продукции, Пресс-бюро снабжало своей информацией, основанной на сообщениях корреспондентов, местные газеты и правительство. Для правительства делались закрытые сообщения. В день Пресс-бюро выпускало около 20 сообщений для прессы в 24-30 экз. каждое и 30 сообщений в 10 экз. для правительства ${ }^{9}$. Официально Пресс-бюро издавало только одну газету - «Вестник ВПП», но его услугами пользовались еще два про-

\footnotetext{
${ }^{5}$ Там же. Д. 3. Л. 6.

${ }^{6}$ Там же. Д. 7. Л. 7-11; Д. 9. Л. 3-4.

${ }^{7}$ [Иванов Вс. Н.]. Скандалисты // Вечерняя газета (Владивосток). 1921.8 сент.

${ }^{8}$ [Иванов Вс. Н.]. $100 / /$ Вечерняя газета. 1921. 26 сент.

${ }^{9}$ РГИА ДВ. Ф. Р-718. Оп. 1. Д. 3. Л. 3 об.
} 
правительственных издания - газета «Русский край» и «Вечерняя газета» (о которой речь еще впереди). Меркуловская власть помогала своей прессе тем, что закупала часть тиражей этих газет, а затем бесплатно распространяла их через экспедицию Пресс-бюро наряду с правительственными материалами [6, с. 12]. С типографских станков Пресс-бюро почти ежедневно сходила новая пропагандистская листовка, только к 8 июня 1921 г. таковых было выпущено 7 наименований («Гражданам об атамане Семенове», «О сельском управлении», «К русскому населению» и др.). Выходили пропагандистские листки, адресованные противникам Меркуловых: «Партизане!», «К Красной армии» и т.д. Изредка Пресс-бюро выпускало и более солидную литературу: была издана, например, тиражом 1000 экз. брошюра протоиерея Антоньева «Почему я не могу быть коммунистом» ${ }^{10}$. Листовки Пресс-бюро, как правило, имели тираж 20 тыс. экз.

В течение лета 1921 г. была сформирована некоторая, хотя и не очень густая сеть распространения изданий Пресс-бюро на территории Приморья. На местах работали агенты Пресс-бюро, отвечавшие за распространение литературы во вверенном им районе. Уже 18 августа 1921 г. экспедиция Пресс-бюро ежедневно рассылала 1300 экз. газеты «Русский край» и 1500 экз. «Вечерней газеты», «Вестник ВПП», листовки и брошюры. «Летучек», воззваний и брошюр рассылалось до 136 тыс. в месяц ${ }^{11}$. Литература поступала также в адреса 11 волостных земских управ для раздачи по деревням (от 2 до 5 экз. газет на каждую) $)^{12}$.

Но такую рассылку все признавали недостаточной. Газеты и листовки запрашивали у Пресс-бюро воинские части, осведомительные школы при Особом отделе Штаба войск, сельские священники. Экспедиция Пресс-бюро засылала свои издания в националистическую организацию «Русское обновленное общество», отправляла их со специальными рассыльными по линии Уссурийской железной дороги, снабжала капитанов пароходов «для передачи представителям русской власти» на причалах по пути следования ${ }^{13}$. Стоило только особоуполномоченному ВПП по НикольскУссурийскому району Н.И. Кузьмину пожаловаться в Пресс-бюро на плохое снабжение литературой своего района, как в Никольск-Уссурийск и крупнейшие села (Раздольное, Кневичи, Евгеньевка) выехал с проверкой помощник экспедитора Пресс-бюро А.П. Пушков ${ }^{14}$.

В должности уполномоченного по информации ВПП Вс. Н. Иванов находился до октября 1921 г., затем на этом посту появился другой представитель ВПП - Л.Д. Тяжелов (чья фамилия, как вариант замены Вс. Н. Иванова, появлялась в документах еще в июне $)^{15}$.

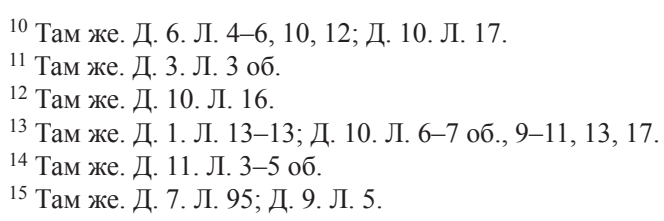

Уйдя с поста руководителя информацией, Вc. Н. Иванов сосредоточился на том, что считал своим главным делом в «меркуловском» Приморье - на редактировании ежедневной «Вечерней газеты». Случайно или нет, но эта газета явилась ровесницей переворота: ее первый номер вышел днем 26 мая 1921 г., когда по городу еще кружили автомобили с боевыми группами «каппелевцев» (разрешение на ее выпуск Иванов получил от «антоновских» властей буквально накануне). По словам Вс. Н. Иванова, первый номер газеты (с объявлением о перевороте) разошелся тиражом 20 тыс. экз. [5, с. 377], что для Владивостока того времени было феноменальным достижением.

Задачи газеты Вс. Н. Иванов видел «в осознании происходящей действительности, которая во многом напоминает действительность сумасшедшего дома» ${ }^{16}$. Редактор не ошибся: все время, пока он находился у кормила редакции, «Вечерняя газета» и события вокруг нее носили нервный, «дуэлянтский», временами скандальный характер. В разгар политической борьбы иного и не могло быть. Газета и ее редактор состояли в постоянном конфликте с другими периодическими изданиями - представителями соперничающих политических сил. До 7 июля 1921 г. - последнего дня выборов в Народное собрание «меркуловского» Приморья - страницы газеты были заполнены агитацией за предвыборный список № 7, выдвинутый Советом съезда несоциалистических организаций.

В те дни Вс. Н. Иванов всецело поддерживал «несосов». Но уже осенью 1921 г., по мере развертывания конфликта между Советом съезда и ВПП в персональном облике С.Д. и Н.Д. Меркуловых, Иванов меняет свои политические позиции. От легких упреков правых депутатов Народного собрания (Нарсоба) в отходе от идеалов 1-го несоциалистического съезда «с его горячим идейным трепетанием единого национального понимания» ${ }^{17}$, Вс. Н. Иванов переходит к открытому противостоянию с руководителями Совета несоциалистического съезда Н.А. Андрушкевичем, С.М. Широкогоровым и др. Они, по мнению Иванова, «почили в самодовольстве высшего бюрократизма» и, опираясь на большинство Нарсоба, плетут интриги против Меркуловых, подтачивают устои «национально-демократической власти». «Не возглавлять русское дело может ваша компания, - восклицает Вс. Н. Иванов, - а его дискредитировать. Совет ваш стал Совдепом, источником разрухи и развала, собранием каких-то действий и выступлений исключительно на почве мелких самолюбий» ${ }^{18}$

Прошло еще немного времени - и в начале 1922 г. Всеволод Никанорович сначала сдержанно, а

\footnotetext{
16 [Иванов Вс. Н.]. От редакции // Вечерняя газета. 1921. 26 мая.

17 [Иванов Вс. Н.]. Декларация В.Ф. Иванова // Вечерняя газета. 1921. 14 сент.

${ }^{18}$ Иванов Bc. Н. Упразднили (Вынужденный ответ) // Вечерняя газета. 1921. 30 дек.
} 
затем все более резко стал выступать против лидера «несосов» в Нарсобе - своего бывшего друга и бывшего премьера ВПП В.Ф. Иванова ${ }^{19}$, который, как выяснилось позже, и был главным «архитектором» внутреннего заговора против Меркуловых [5, с. 393]. Сам же Вс. Н. Иванов до конца оставался верным «меркуловцем». Новый 1922 г. он встретил в занятом (на время) белоповстанцами Хабаровске, куда уехал как журналист сопровождать Н.Д. Меркулова и его делегацию ${ }^{20}$.

С февраля 1922 г. меняется непримиримый тон Bc. Н. Иванова в отношении Советской России, в которой набирает темпы новая экономическая политика. Читая советскую прессу, Иванов трактует в передовых статьях «Вечерней газеты» НЭП как долгожданное возвращение к нормальному «капиталистическому строю». «То-то и есть, идиоты! - пишет он. - На какой же черт надо было бороться 4 года и расстреливать публику!» ${ }^{21}$.

Работа официальных пропагандистских служб меркуловского режима неожиданно закончилась поздней осенью 1921 г. 5 ноября ВПП приняло решение об упразднении должности уполномоченного по информации, информационного отдела и Прессбюро, а 10 ноября сотрудники последнего, включая Л.Д. Тяжелова и Г.Г. Недлера, получили уведомления об увольнении ${ }^{22}$

Активное ядро антикоммунистической журналистики, возможно, вполне сознательно переформатировало таким способом свою деятельность. Уже в начале ноября 1921 г. во Владивостоке был создан Дальневосточный союз русских журналистов - из сотрудников «местных и частью харбинских органов несоциалистической прессы». Союз, в сущности, повторял структуру ликвидированного Прессбюро: в его состав входили телеграфное агентство «Национал-пресс» и издательский отдел. О своем отношении к ВПП создатели новой организации писали: «Союз не является организацией правительственной, но Союз не скрывает и своего духовного сродства с местной национальной властью и своей всегдашней готовности содействовать местному национальному Приамурскому правительству» ${ }^{23}$.

По существу, повторилась комбинация, реализованная в колчаковском Омске в мае 1919 г., когда на смену казенному Пресс-бюро в составе правительства пришло «общественное» и «независимое» издательство - Акционерное «Русское общество печатного дела» (АО РОПД). В создании Дальневосточного союза русских журналистов активное участие приняли Вс. Н. Иванов (рекламировавший Союз в сво-

19 [Иванов Вс. Н.]. К созыву третьего съезда // Вечерняя газета. 1922. 3 янв.; Иванов Вс.Н. Голоса с улицы // там же. 21 февр.

${ }^{20}$ Иванов Вс. Н. В Хабаровск (Дорожные впечатления) // Вечерняя газета. 1922. 10 янв.

21 [Иванов Вс. Н.]. Из советских газет // Вечерняя газета. 1922 17 февр.

22 РГИА ДВ. Ф. Р-718. Оп 1. Д. 3. Л. 1-2.

23 Там же. Ф. Р-758. Оп 1. Д. 1. Л. 3-4. ей газете $)^{24}$ и еще один бывший деятель АО РОПД - юрист и издатель Яков Леонидович Белоблоцкий, хорошо известный Иванову по бурной работе в Новониколаевском отделении РОПД. В составе учредителей Союза были также П.П. Васильев, С.П. Руднев, Н.И. Сахаров и др.

Издательский отдел Союза, начавший работать 15 ноября 1921 г. под руководством Я.Л. Белоблоцкого, уже к 31 декабря выпустил 130 тыс. различных листовок и воззваний ВПП, многие из которых готовились в спешном порядке. «Отдел, - писал Я.Л. Белоблоцкий в отчете, - имел в своем распоряжении не больше 10 часов с момента получения темы для листовки и [до] сдачи нескольких тысяч отпечатанных листовок». До конца года издательский отдел выпустил 2 номера газеты «Приморский крестьянин» и 3 номера газеты «Народное дело» (с 1922 г. она стала издаваться дважды в неделю тиражом 5 тыс. экз.). Отдел заключил договор с Уссурийской железной дорогой об аренде на 6 месяцев всех дорожных газетных киосков и исключительном праве продажи печатных изданий отдела на 6 крупных железнодорожных станциях, а также в поездах. К началу 1922 г. в портфеле издательства имелись брошюры «Экономическое положение Совроссии», «Сибирь при большевиках», «Деятели ДВР», «Земство и большевики». Печатались циклы листовок «Советская Россия в 1921 г.», «Что делается в ДВР», «В национальном Приморье» $^{25}$.

В конце 1921 г. организаторы Союза журналистов и Национал-пресс приобрели у бывших владельцев - Съезда несоциалистических организаций - газету «Слово» $[6$, с. 12]. В полную собственность Национал-пресс фактически перешла и газета «Русский край». Осваивая новую площадку своей деятельности, Вс. Н. Иванов с 20 ноября 1921 г. по 13 февраля 1922 г. поместил в «Русском крае» 12 своих стихотворений и 3 литературно-публицистических статьи. Кроме редактирования «Вечерней газеты», Иванов в 1922 г. выпускал нерегулярное издание - газету «Вечерняя звезда», которая выходила «по праздникам в 12 часов дня». Газета увидела свет лишь 6 раз - 19, 24 марта, 23 апреля (в Пасху), 14 мая (на Троицу), 12 июня и 28 сентября вышли ее экстренные выпуски. После завершения борьбы за власть между Меркуловыми и Нарсобом, с 16 июля по 3 августа 1922 г. Вс. Н. Иванов редактировал еще одну газету - «Вестник национального движения» («орган несоциалистических организаций города»). Под его редакцией во Владивостоке очень недолго издавался небольшой чисто литературный журнал.

Речи нового правителя Приморья - «воеводы Земской Рати» М.К. Дитерихса - на Земском соборе произвели на Вс. Н. Иванова (как и на С.П. Руднева)

${ }^{24}$ Иванов Вс. Н. По поводу Национал-пресс // Вечерняя газета. 1921. 24 нояб.

${ }^{25}$ РГИА ДВ. Ф. Р-758. Оп. 1. Д. 2. Л. 1-2, 4-6. 
удручающее впечатление. «Ни разу больше, - вспоминал Иванов, - ни в каком учреждении “Земского края" не бывала моя нога» [5, с. 395]. Из Владивостока Вс. Н. Иванов отплыл в эмиграцию 22 октября 1922 г., за три дня до вступления в город «красных» войск ДВР и партизан.

Эпопея кипучей деятельности Вс. Н. Иванова в стане «меркуловцев» вместила в себя многое: энтузиазм первых месяцев, разочарование в друзьях и идеалах, выстраивание работы редакций и издательских организаций, радость творчества и горечь расставания с Родиной. Не поместилось в ней только примирение с большевистской Россией - слишком свежи были раны прошедших лет. Осознание своей сопричастности судьбе страны, перекроенной революцией, пришло к писателю спустя десятилетие, в начале 1930-х гг.

\section{СПИСОК ЛИТЕРАТУРЫ}

1. Якимова С.И. Всеволод Никанорович Иванов: писатель, мыслитель, журналист. Хабаровск : Изд-во ТОГУ, 2013. 215 с.

2. Всеволод Никанорович Иванов - писатель и философ: к 125 -летию со дня рождения писателя : биобиблиогр. указ. / сост. Т.В. Кирпиченко. Хабаровск, 2013. 84 с.

3. «Непрерывное движение духа...»: Дневник и записные книжки Вс. Н. Иванова. Хабаровск, 2012. 380 с.
4. Ситников М.Г. Редактор газеты «Сибирские стрелки» // Белая армия. Белое дело: ист. науч.-популяр. альманах. Екатеринбург, 2011. № 19. С. 55-97.

5. Иванов Bc. Н. Исход: воспоминания / В.Н. Иванов; под общ. ред. М.Ф. Асламова. Хабаровск: Союз писателей России, Хабар. регион. отд-ние, 2008. 400 с.

6. Владивосток, 1922 год: жизнь города на страницах газеты «Голос Родины» / сост. и ред. Н.А. Троицкая. Владивосток : Рос. гос. ист. архив Дальнего Востока, 2012. 138 с.

\section{REFERENCES}

1. Yakimova S.I. Vsevolod Nikanorovich Ivanov: a writer, thinker, journalist. Khabarovsk, 2013, 215 p. (In Russ.)

2. Vsevolod Nikanorovich Ivanov - a writer and philosopher: on the 125th anniversary of the writer: biobibliographic index / comp. T.V. Kirpichenko. Khabarovsk, 2013, 84 p. (In Russ.)

3. "Spirit continuous movement ...": a diary and notebooks by Vs. N. Ivanov. Khabarovsk, 2012, 380 p. (In Russ.)

4. Sitnikov M.G. Editor of newspaper "Sibirskiye Strelki". Belaya armiya. Beloye delo: Ist. nauch.-popular. alm. Ekaterinburg, 2011, no 19, pp. 55-97 (In Russ.)

5. Ivanov VS. N. Exodus: Memoirs. Khabarovsk, 2008, 208 p. (In Russ.)

6. Vladivostok 1922: city life on pages of newspaper "Golos Rodiny" / comp. a. ed. N.A. Troitskaya. Vladivostok, 2012, 138 p. (In Russ.)

Статья принята редакиией 20.07.2015

DOI: $10.15372 / \mathrm{HSS} 20150310$

УДК 002.5(09)

\title{
Н.С. ЛИСОВСКАЯ
}

\section{НАУЧНЫЕ ИЗДАНИЯ СИБИРСКИХ ФИЛИАЛОВ АКАДЕМИИ НАУК (1946-1950-е гг.)}

\author{
Наталья Сергеевна Лисовская, \\ заведующая сектором, \\ Государственная публичная научно-техническая библиотека СО РАН, \\ РФ, 630200, г. Новосибирск, ул. Восход, 15 \\ e-mail: linaseveda@mail.ru
}

В статье поставлена цель - воссоздать историю зарождения научной периодики сибирских филиалов Академии наук СССР в 1946 1950-е гг. В качестве источниковой базы привлекались библиографические указатели, архивные документы, материалы академической периодической печати, а также сами издания «de visu». В результате было установлено, что выпуск научных изданий сибирскими академическими коллективами на момент организации Сибирского отделения явился важным подготовительным этапом в процессе дальнейшего развития системы научной периодики. Инициатива и активная поддержка Академии наук СССР объединила усилия филиалов в создании первого регионального журнала - «Известия восточных филиалов АН СССР» и во многом способствовала дальнейшему развитию издательской деятельности.

Ключевые слова: научные издания, научные журналь, “Известия Восточных филиалов Академии наук», издательская деятельность, Академия наук СССР, Западно-Сибирский филиал, Якутский филиал, Восточно-Сибирский филиал. 